\title{
Silver Modified Hydrophytes for Heavy Metal Removal from Different Water Resources
}

\author{
Fatma Refaat El Awady ${ }^{1 \mathbb{C}}$, Muhammad Ali Abbas ${ }^{1[}{ }^{\mathbb{D}}$, Amr Muhamad Abdelghany ${ }^{2, *(\mathbb{D}}$, Yasser Ahmed \\ El-Amir 1,*iD \\ Botany Department, Faculty of Science, Mansoura University, Mansoura, 35516, Egypt \\ Spectroscopy Department, Physics Division, National Research Centre, 33 Elbehouth st., 12311, Dokki, Giza, Egypt \\ Correspondence: yasran@mans.edu.eg (Y.E.), a.m._abdelghany@yahoo.com (A.A.);
}

Scopus Author ID 55791223000

Received: 11.02.2021; Revised: 6.03.2021; Accepted: 10.03.2021; Published: 23.03.2021

\begin{abstract}
Phytoremediation of three different aquatic plants powders Lemna minor L., Azolla filiculoides Lam. and Pistia stratiotes L. studied against different heavy metals (HM) and after modifications with interfacial layer synthesized silver nanoparticles. Prepared samples tested for the selective absorbance of chromium, cadmium, lead, and zinc. L. minor and P. stratiotes show selective absorption against lead, while Azolla filiculoides show higher absorption against chromium. Absorption of all heavy metal concentrations was found to be enhanced after interfacial modification with green synthesized silver nanoparticles.
\end{abstract}

Keywords: aquatic plants; silver nanoparticles, heavy metal; phytoremediation.

(C) 2021 by the authors. This article is an open-access article distributed under the terms and conditions of the Creative Commons Attribution (CC BY) license (https://creativecommons.org/licenses/by/4.0/).

\section{Introduction}

Water is the essential substance after the air, with the importance of water being the second place as an essential requirement. Life as we know it could not have evolved without water; that is, water is also used by all living organisms [1, 2]. During the last decades, removing heavy metal ions from contaminated water may be considered an important issue for different uses, including agriculture [3, 4] and industrial uses [5, 6]. Various materials that were reported to be used, including organic [5], inorganic [7], agro-waste materials [8], and many others, were reported. Phytoremediation can be considered an effective and green developing route with long-range applicability when suitable plants were chosen. Aquatic plants were recently studied [9]. Several authors have reviewed floating and emergent aquatic plants' applications in phytoremediation processes for water contaminated with heavy metals $[3,10$ 13].

Plants that may be used in the phytoremediation process must have specific standards. Plants for this issue must be native with a quick growth rate with a high biomass yield. Besides, it must have higher heavy metal uptake and have the ability to transport metals in aboveground parts of the plant $[14,15]$. Among the various aquatic plant species, Azolla, Eichhornia, Lemna, Potamogeton, Pistia, Typha, Phragmites, and Wolfia have been reported phytoremediators, and also they are highly efficient in reducing aquatic contamination through bioaccumulation of contaminants in their body tissues $[3,16,17]$.

Azolla filiculoides Lam. (family Azollaceae) is a free-floating annual aquatic fern, fastgrowing, and high reproduction rate. Lemna minor L. (duckweed, family Lemanaceae) is a 
small free-floating annual aquatic plant on or beneath the surface water. Pistia stratiotes L. (Water lettuce, family Araceae) is a perennial monocotyledon aquatic plant that free-floating. Three genera are cosmopolitan distributed worldwide, in Egypt, two species of Azolla, three species of Lemna, and one Pistia species distributed in the Nile delta in all water bodies and rice fields $[18,19]$.

They pointed to the metal accumulation character of different aquatic plants, including Azolla, Pistia, and Lemna, along with some other aquatic plants. They also reported that their phytoremediation potential could be further improved. Therefore, the presented work aims to introduce a new novel method for modifying the interfacial surface of plant powder with a silver nanoparticle as an antibacterial agent to enhance some aquatic plants' phytoremediation process to study the selectivity of each plant for a specific element.

\section{Materials and Methods}

\subsection{Collection and preparation of the plants.}

The three selected fresh hydrophytes for the experiment are commonly available in Egyptian water bodies, particularly around the River Nile system as following: Azolla filiculoides Lam. and Lemna minor L. In the laboratory, the three selected plants were washed gently in distilled water several times and have been dried well then, each one of dried plants was put in a blender until it became a soft powder then each plant powder were put in a plastic bag ready for the next steps.

\subsection{Modification with silver nanoparticles.}

The pre-calculated concentration of green synthesized silver nanoparticles was added to $5 \mathrm{gm}$ powdered plant placed in a $100 \mathrm{ml}$ Teflon lined autoclave adjusted at about $50{ }^{\circ} \mathrm{C}$ for about $24 \mathrm{~h}$. the powder was then dried in a vacuum dryer adjusted at the same temperature for another $24 \mathrm{~h}$.

\subsection{Preparation of the standard heavy metal solution.}

Four different heavy metals, Chromium, Zinc, Cadmium, and lead, were selected to test the test plant's selectivity for absorption. A stock solution $(1000 \mathrm{mg} / \mathrm{L})$ was prepared in distilled water with analytical grade $\mathrm{K}_{2} \mathrm{Cr}_{2} \mathrm{O}_{7}, \mathrm{ZnSO}_{4} .7 \mathrm{H}_{2} \mathrm{O}, \mathrm{CdCl}_{2}$, and $\mathrm{Pb}\left(\mathrm{C}_{2} \mathrm{H}_{3} \mathrm{O}_{2}\right) .3 \mathrm{H}_{2} \mathrm{O}$, which was later diluted as required. The plants were maintained in tap water supplemented with 2, 3, 4 $\mathrm{mg} / \mathrm{L}$ of Cr, 5, 10, $20 \mathrm{mg} / \mathrm{L}$ of Zn, 0.5, 1, $2 \mathrm{mg} / \mathrm{L}$ of Cd, and 10, 20, $30 \mathrm{mg} / \mathrm{L}$ of Pb.

\subsection{Simple multi-stage purification system.}

A multi-stage system was adopted to treat contaminated water samples containing different heavy metals. The system consists of five to seven layers. The first layer represents a thick layer of cotton or charcoal in the burette's bottom to prevent the second layer of plant powder from being lost or plugging the burette. The third and fifth layers are represented by small gravel that prevents solid contaminated materials from being passed. In case of heavily contaminated water, two additional layers of powder plant and gravel were added. The thickness of layers was adjusted to a range between $2-2.5 \mathrm{~cm}$. Figure 1 represents a simple multi-stage purification system. 


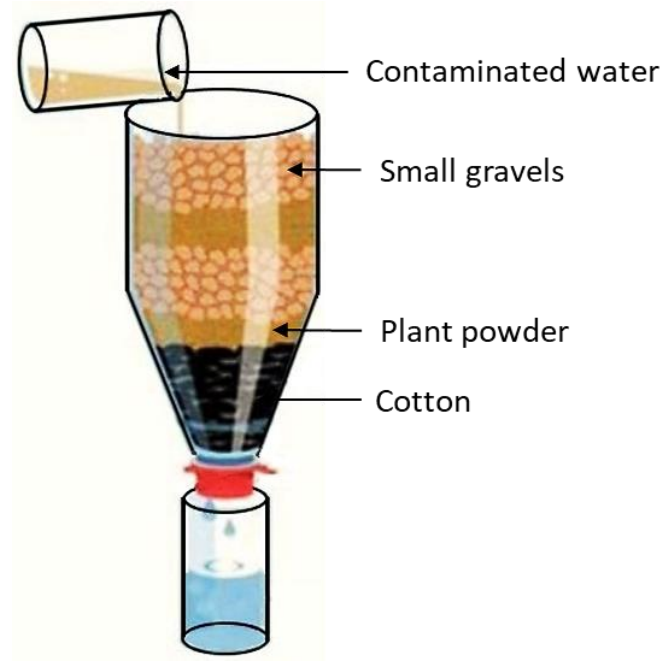

Figure 1. Simple multi-stage purification system.

The flow rate can be adjusted through the burette tape. For fair comparison and to eliminate the factor of time or flow rate, the flow rate was adjusted in all measurements to be $250 \mathrm{ml} / \mathrm{h}$. $25 \mathrm{ml}$ of contaminated water was poured into the burette's upper opening, and purified water samples were collected from the tape. The process was repeated for the same water sample contaminated with a specific element three times, and an average value of triplicate measured parameters was recorded. The system compartment was changed both with changing concentration and/or heavy metal. The processes were repeated for three different plant powders, namely (A. filiculoides, L. minor, and P. stratiotes) and 4 different contaminants $(\mathrm{Pb}, \mathrm{Cd}, \mathrm{Zn}$, and $\mathrm{Cr})$.

\subsection{Determination of the absorbance and concentration of heavy metals in water samples.}

The absorbance of synthetic wastewater was carried out by Atomic Absorption Spectrophotometer (Metertech SP-8001 UV/Visible Spectrophotometer). Determination of heavy metal $(\mathrm{Cd}, \mathrm{Cr}, \mathrm{Pb}$, and $\mathrm{Zn})$ contents in synthetic wastewater were carried out by Atomic Absorption Spectrometer (Buck Scientific Accusys 211 Atomic Absorption Spectrophotometer, USA) with air-acetylene flame at the wavelength of 228.8, 357.87, 283.31 and 213.9, respectively [20-22]. The concentration of metals in the samples was determined in $\mathrm{mg} / \mathrm{L}[23]$.

\subsection{Calculation methods.}

The percentage removal was calculated from the initial and final concentration of metal according to Tanhan et al. [24].

$$
\% \text { Removal }=\frac{\left(C_{0}-C_{f}\right.}{C_{0}}
$$

Where $\mathrm{C}_{0}$ and $\mathrm{C}_{f}$ are initial and remaining concentrations respectively in the medium $(\mathrm{mg} / \mathrm{L})$.

\subsection{Statistical analysis.}

The experiment was set up in replicates, and all the data was mean of triplicate $(n=3)$. Data of both absorbance and the calculated values for removal efficiency were subjected to 
one-way ANOVA followed by Duncan's post hoc test at probability level 0.05 using CoStat software program (CoHort Software, Monterey, CA, USA).

\section{Results and Discussion}

The application of nanoparticles provides an effective alternative method for mitigating various environmental stresses, including heavy metal stress [25]. In the present study, Table 1 reveals the value of absorbance and removal percent of a pre-prepared solution containing heavy metals $(\mathrm{Cr}, \mathrm{Cd}, \mathrm{Pb}$, and $\mathrm{Zn})$ before and after being modifying the Lemna minor powder with silver nanoparticles. It was clear from the experimental data that the removal percentage generally higher in the case of plant powder modified with silver nanoparticles by about $22 \%$ of the original value for chromium ions and $15 \%$ for cadmium ions, $4 \%$ for lead, and $91 \%$ for zinc respectively at lower concentrations $(2,0.5,5$ and $10 \mathrm{ppm})$ which decrease with increases of some heavy metal concentration $(\mathrm{Cr}, \mathrm{Pb}$, and $\mathrm{Cd})$ and increase in $10 \mathrm{ppm}$ then decrease in $20 \mathrm{ppm}$ of $\mathrm{Zn}$.

\subsection{Removal capacity of Lemna minor.}

It was also observed that L. minor best removal percentage combined with $\mathrm{Zn}$ ions. Similar results were obtained by Neidoni et al. [26] observed that it had been an increased affinity for zinc accumulation (72\% removal at the initial concentration of $15 \mathrm{mg} / \mathrm{L} \mathrm{Zn}$ ) than copper and nickel. Kinraide et al. [27] reported that Zn excess and Zn deficiency cause Zn to become prooxidant. As a result, various sets of proteins responsible for sensing, carrying, buffering, holding, and releasing $\mathrm{Zn}$ closely regulate the cellular concentration and compartmentation of mobile $\mathrm{Zn}$ in all organisms [28]. Figure 1 shows the relative change in absorbance for different metal concentrations $(\mathrm{Cr}, \mathrm{Cd}, \mathrm{Pb}$, and $\mathrm{Zn}$ ) before and after modifying the L. minor powders with silver nanoparticles.

Table 1. Absorbance and removal percent of the pre-prepared solution containing heavy metals $(\mathrm{Cr}, \mathrm{Cd}, \mathrm{Pb}$, and

\begin{tabular}{|c|c|c|c|c|c|}
\hline \multirow{2}{*}{ Element } & \multirow{2}{*}{ Conc. (ppm) } & \multicolumn{2}{|c|}{ Without nanoparticles } & \multicolumn{2}{|c|}{ With nanoparticles } \\
\hline & & Absorbance & \% removal & Absorbance & \% removal \\
\hline \multirow{3}{*}{$\mathrm{Cr}$} & 2 & 0.458 & 77.12 & 0.116 & 94.22 \\
\hline & 3 & 0.618 & 79.40 & 0.314 & 89.54 \\
\hline & 4 & 0.757 & 81.07 & 0.426 & 89.36 \\
\hline \multirow{3}{*}{$\mathrm{Cd}$} & 0.5 & 0.112 & 77.68 & 0.652 & 89.6 \\
\hline & 1 & 0.219 & 78.13 & 0.130 & 86.99 \\
\hline & 2 & 0.199 & 90.04 & 0.341 & 82.97 \\
\hline \multirow{3}{*}{$\mathrm{Pb}$} & 10 & 0.563 & 94.37 & 0.191 & 98.19 \\
\hline & 20 & 0.431 & 97.84 & 0.410 & 97.95 \\
\hline & 30 & 0.368 & 98.77 & 0.571 & 98.10 \\
\hline \multirow{4}{*}{$\mathrm{Zn}$} & 5 & 0.334 & 93.31 & 0.745 & 85.09 \\
\hline & 10 & 0.537 & 94.63 & 0.566 & 94.34 \\
\hline & 20 & 3.013 & 84.93 & 2.407 & 87.97 \\
\hline & $\mathrm{LSD}_{0.05}$ & $0.016 * * *$ & $0.807 * * *$ & $0.004 * * *$ & $0.298 * * *$ \\
\hline
\end{tabular}

\subsection{Removal capacity of Azolla filiculoids.}

Table 2 discloses the value of absorbance and removal percent of the pre-prepared solution containing heavy metals before and after modifying the Azolla filiculoids powders with silver nanoparticles. It was clear that the removal percentage generally higher in the case of plant powder modified with silver nanoparticles by about $10 \%$ of the original value for chromium ions and $30 \%$ for cadmium ions, $22 \%$ for lead, and $14 \%$ for zinc, respectively, at 
lower concentrations (2, 0.5, 10 and 5) which decrease with increases of heavy metal concentration $(\mathrm{Cr}, \mathrm{Pb}$, and $\mathrm{Zn})$ except in $\mathrm{Cd}$ removal percentage there is an increase in removal percentage in high $\mathrm{Cd}$ concentration $(2 \mathrm{ppm})$.

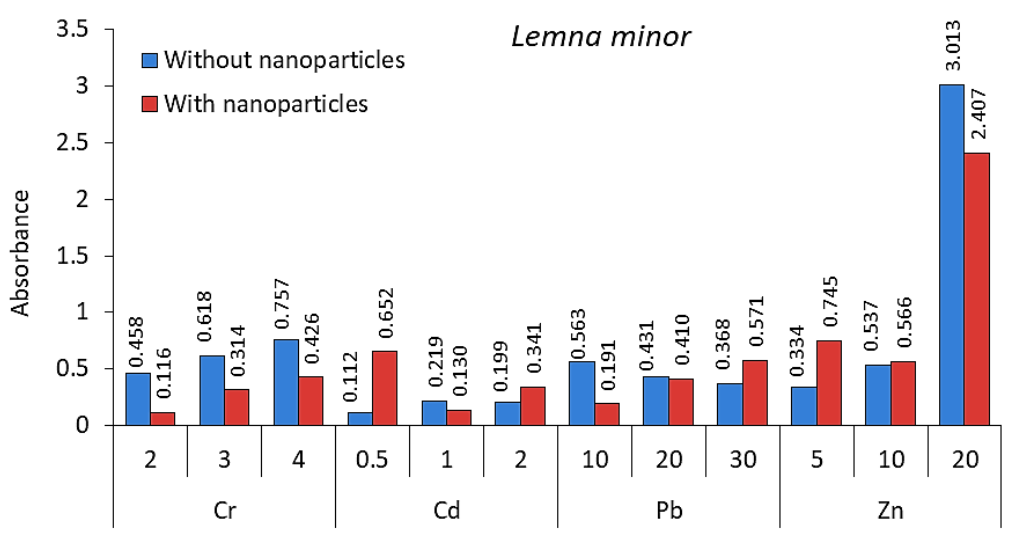

Heavy metals concentration (ppm)

Figure 1. Relative change in absorbance for different metal concentrations before and after modifying the Lemna minor powders with silver nanoparticles.

It was also observed that $A$. filiculoides best removal percentage combined with $\mathrm{Cd}$ ions. It was concluded that the removal percentage increases with modifying plant powder with silver nanoparticles. The bioaccumulation potential of Azolla spp. for various heavy metals has been compared with other aquatic macrophytes by many workers [29-31].

Table 2. Absorbance and removal percent of a pre-prepared solution containing heavy metals before and after modification of the Azolla filiculoids powders with silver nanoparticles.

\begin{tabular}{|c|c|c|c|c|c|}
\hline \multirow{2}{*}{ Element } & \multirow{2}{*}{ Conc. (ppm) } & \multicolumn{2}{|c|}{ Without nanoparticles } & \multicolumn{2}{|c|}{ With nanoparticles } \\
\hline & & Absorbance & \% removal & Absorbance & \% removal \\
\hline \multirow{3}{*}{$\mathrm{Cr}$} & 2 & 0.135 & 93.25 & 0.109 & 94.57 \\
\hline & 3 & 0.399 & 86.69 & 0.177 & 94.09 \\
\hline & 4 & 0.453 & 88.67 & 0.286 & 92.85 \\
\hline \multirow{3}{*}{$\mathrm{Cd}$} & 0.5 & 0.229 & 54.18 & 0.147 & 70.70 \\
\hline & 1 & 0.340 & 65.98 & 0.264 & 73.61 \\
\hline & 2 & 0.237 & 88.15 & 0.423 & 78.84 \\
\hline \multirow{3}{*}{$\mathrm{Pb}$} & 10 & 3.558 & 64.42 & 2.119 & 78.81 \\
\hline & 20 & 9.929 & 50.35 & 8.454 & 57.73 \\
\hline & 30 & 16.620 & 44.60 & 11.745 & 60.85 \\
\hline \multirow{4}{*}{$\mathrm{Zn}$} & 5 & 1.840 & 63.20 & 1.3787 & 72.43 \\
\hline & 10 & 3.677 & 63.24 & 2.7476 & 72.52 \\
\hline & 20 & 5.015 & 74.93 & 5.4087 & 72.96 \\
\hline & $\mathrm{LSD}_{0.05}$ & $0.007 * * *$ & $0.115 * * *$ & $0.002 * * *$ & $0.117 * * *$ \\
\hline
\end{tabular}

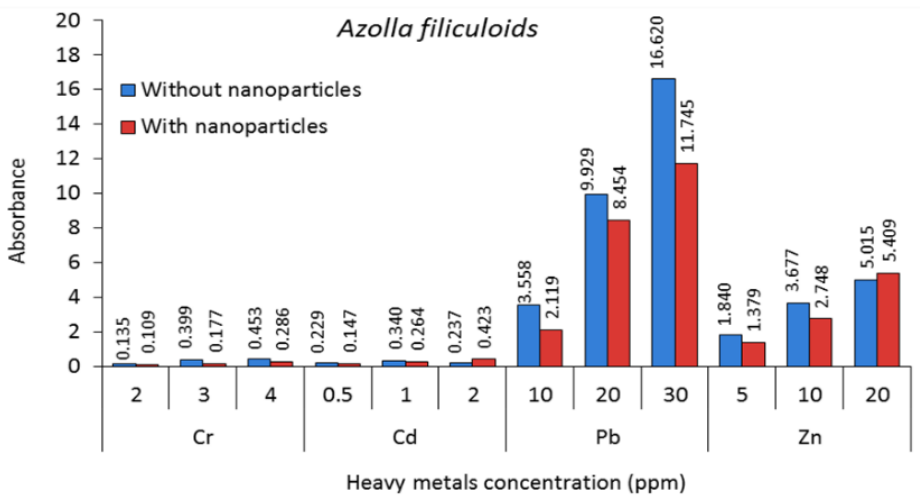

Figure 2. Relative change in absorbance for different metal concentrations before and after modifying the Azolla filiculoides powders with silver nanoparticles. 
They reported that A. filiculoides accumulate heavy metals in tissues such as $\mathrm{Cd}, \mathrm{Cr}$, and $\mathrm{Zn}$ from wastewater. Similar findings were observed by Khosravi et al. [32] showed that the maximum uptake capacities of heavy metals $(\mathrm{Cd}, \mathrm{Pb}$, and $\mathrm{Zn})$ after chemical modifying the A. filiculoids powders were increased in wastewater. Figure 2 displays the relative change in absorbance for different metal concentrations $(\mathrm{Cr}, \mathrm{Cd}, \mathrm{Pb}$, and $\mathrm{Zn})$ before and after modifying the A. filiculoides plant powders with silver nanoparticles.

\subsection{Removal capacity of Pista stratiotes.}

Table 3 discloses the value of absorbance and removal percent of a pre-prepared solution containing heavy metals $(\mathrm{Cr}, \mathrm{Cd}, \mathrm{Pb}$, and $\mathrm{Zn})$ before and after being modifying the Pista stratiotes plant powders with silver nanoparticles. It was clear that the removal percentage generally higher in the case of plant powder modified with silver nanoparticles by about $6 \%$ of the original value for chromium ions and $19 \%$ for cadmium ions, $0 \%$ for lead and $1 \%$ for zinc, respectively, at lower concentrations $(2,0.5,10$ and $5 \mathrm{ppm})$ which decrease with increases of heavy metal concentration especially in all $(\mathrm{Cd})$ concentration and $(\mathrm{Pb})$ concentration with concentration and $(\mathrm{Zn})$ concentration with (10 ppm) Then decrease in (30 ppm).

It was observed that $P$. stratiotes best removal percentage combined with $\mathrm{Cd}$ ions. It was concluded that the removal percentage increases with modifying plant powder with silver nanoparticles.

Table 3. Absorbance and removal percent of the pre-prepared solution containing heavy metals before and after modification of the Pistia stratiotes plant powders with silver nanoparticles.

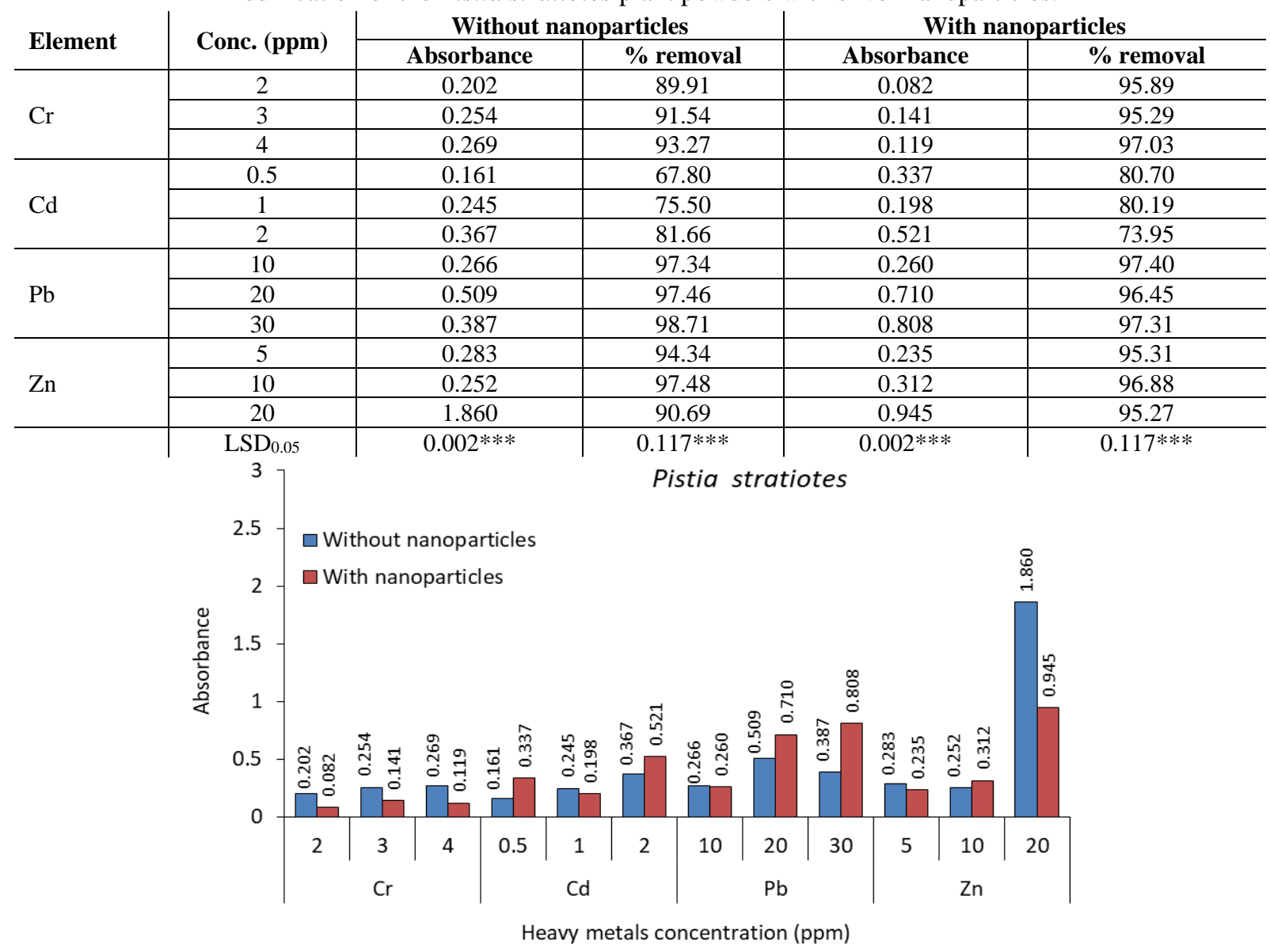

Figure 3. Relative change in absorbance for different metal concentrations before and after modifying the Pistia stratiotes plant powders with silver nanoparticles. 
Similar results were observed by Miretzky et al. [33] and by Rodrigues et al. [34] found that $P$. stratiotes biomass can be effectively used for the removal of $\mathrm{Cd}$ and $\mathrm{Zn}$ from contaminated water bodies, with its efficiency being related to the immersion time and the concentration of these elements in the solution. Figure 3 shows the relative change in absorbance for different metal concentrations $(\mathrm{Cr}, \mathrm{Cd}, \mathrm{Pb}$, and $\mathrm{Zn})$ before and after modifying the $P$. stratiotes powders with silver nanoparticles.

According to a literature survey, floating aquatic plants have been shown to exhibit a higher accumulation of metals $(\mathrm{Cd}, \mathrm{Pb}, \mathrm{Ni}, \mathrm{Zn}$, and $\mathrm{Cu})$ with higher bio-concentration factors than submerged and emergent plants in water $[35,36]$. In the present study, regarding the plant species, percent heavy metals removal was increased in this order: A. filiculoides $<$ L. minor $<$ $P$. stratiotes. The morphological adaptive capacity determines the ability of the plant to absorb contaminants from water. The removal efficiency of any ion in tissues of macrophytes depends on the concentration of that ion in a water environment, physical-chemical characteristics of that pollutant, temperature, $\mathrm{pH}$ of water, and physiological and biochemical properties of the plant $[4,37]$. Finally, studied hydrophytes may be used in "Ecotechnology" (environmental technology) in constructed wetlands. Moreover, wetlands help to prevent the spread of heavy metal contamination from land to the aquatic environment.

\section{Conclusions}

Three different fresh hydrophytes commonly available in Egyptian water bodies, particularly around the River Nile system, namely, Lemna minor, Azolla filiculoides, and Pistia stratiotes were collected, dried, and powdered. Prepared plant powder was modified through an interfacial layer of green synthesized silver nanoparticles. Powdered plants were studied against absorption of three different concentrations of four different heavy metals (HM), namely, chromium, cadmium, lead, and zinc. Obtained data reveals enhancement of HM absorption after modification with nanoparticles in all samples. Besides, studied plants show selective absorption against different metals.

\section{Funding}

This research received no external funding.

\section{Acknowledgments}

This research has no acknowledgment.

\section{Conflicts of Interest}

The authors declare no conflict of interest.

\section{References}

1. Chaplin, M.F. Water: its importance to life. Biochemistry and Molecular Biology Education 2001, 29, 5459, https://doi.org/10.1111/j.1539-3429.2001.tb00070.x.

2. $\quad$ Spellman, F.R. The drinking water handbook. CRC Press. 2017.

3. El-Amier, Y.A.; Bonanomi, G.; Al-Rowaily, S.L.; Abd-ElGawad, A.M. Ecological Risk Assessment of Heavy Metals along Three Main Drains in Nile Delta and Potential Phytoremediation by Macrophyte Plants. Plants 2020, 9, https://doi.org/10.3390/plants9070910.

4. Li, Y.; Wang, L.; Chao, C.; Yu, H.; Yu, D.; Liu, C. Submerged macrophytes successfully restored a subtropical aquacultural lake by controlling its internal phosphorus loading. Environmental Pollution 2021, 268, https://doi.org/10.1016/j.envpol.2020.115949. 
5. Shayegan, H.; Ali, G.A.M.; Safarifard, V. Recent Progress in the Removal of Heavy Metal Ions from Water Using Metal-Organic Frameworks. ChemistrySelect 2020, 5, 124-146, https://doi.org/10.1002/slct.201904107.

6. El-Alfy, M.A.; Darwish, D.H.; El-Amier, Y.A. Land use Land cover of the Burullus Lake shoreline (Egypt) and health risk assessment of metal-contaminated sediments. Human and Ecological Risk Assessment: An International Journal 2020, 1-23, https://doi.org/10.1080/10807039.2020.1786667.

7. Masjedi, A.; Askarizadeh, E.; Baniyaghoob, S. Magnetic nanoparticles surface-modified with tridentate ligands for removal of heavy metal ions from water. Materials Chemistry and Physics 2020, 249, https://doi.org/10.1016/j.matchemphys.2020.122917.

8. Arthi, D.; Michael Ahitha Jose, J.; Edinsha Gladis, E.H.; Shajin Shinu, P.M.; Joseph, J. Removal of heavy metal ions from water using adsorbents from agro waste materials. Materials Today: Proceedings 2020, https://doi.org/10.1016/j.matpr.2020.08.738,

9. Ashraf, S.; Ali, Q.; Zahir, Z.A.; Ashraf, S.; Asghar, H.N. Phytoremediation: Environmentally sustainable way for reclamation of heavy metal polluted soils. Ecotoxicology and Environmental Safety 2019, 174, 714727, https://doi.org/10.1016/j.ecoenv.2019.02.068.

10. Rai, P.K. Heavy Metal Pollution in Aquatic Ecosystems and its Phytoremediation using Wetland Plants: An ecosustainable approach. International Journal of Phytoremediation 2008, 10, 133-160, https://doi.org/10.1080/15226510801913918.

11. Török, A.; Gulyás, Z.; Szalai, G.; Kocsy, G.; Majdik, C. Phytoremediation capacity of aquatic plants is associated with the degree of phytochelatin polymerization. Journal of Hazardous Materials 2015, 299, 371378, https://doi.org/10.1016/j.jhazmat.2015.06.042.

12. Ali, S.; Abbas, Z.; Rizwan, M.; Zaheer, I.E.; Yavaş, İ.; Ünay, A.; Abdel-Daim, M.M.; Bin-Jumah, M.; Hasanuzzaman, M.; Kalderis, D. Application of Floating Aquatic Plants in Phytoremediation of Heavy Metals Polluted Water: A Review. Sustainability 2020, 12, https://doi.org/10.3390/su12051927.

13. El-Amier, Y.; El-Alfy, M.; Nofal, M. Macrophytes potential for removal of heavy metals from aquatic ecosystem, Egypt: Using metal accumulation index (MAI). Plant Archives 2018, 18, 2134-2144.

14. Rue, M.; Paul, A.L.D.; Echevarria, G.; van der Ent, A.; Simonnot, M.-O.; Morel, J.L. Uptake, translocation and accumulation of nickel and cobalt in Berkheya coddii, a 'metal crop' from South Africa. Metallomics 2020, 12, 1278-1289, https://doi.org/10.1039/D0MT00099J.

15. Reeves, R.D.; Baker, A.J.M.; Jaffré, T.; Erskine, P.D.; Echevarria, G.; van der Ent, A. A global database for plants that hyperaccumulate metal and metalloid trace elements. New Phytologist 2018, 218, 407-411, https://doi.org/10.1111/nph.14907.

16. Dhir, B. Phytoremediation: Role of aquatic plants in environmental clean-up. New Delhi: Springer, 2013; pp. 14, https://doi.org/10.1007/978-81-322-1307-9.

17. Rezania, S.; Taib, S.M.; Md Din, M.F.; Dahalan, F.A.; Kamyab, H. Comprehensive review on phytotechnology: Heavy metals removal by diverse aquatic plants species from wastewater. Journal of Hazardous Materials 2016, 318, 587-599, https://doi.org/10.1016/j.jhazmat.2016.07.053.

18. Boulos, L. Flora of Egypt, 1 (Azollaceae - Oxalidaceae). Al-Hadara Publishing, Cairo, Egypt. 1999; https://doi.org/10.1111/j.1756-1051.1999.tb01119.x.

19. Boulos, L. Flora of Egypt, Volume 4: Monocotyledons (Alismataceae-Orchidaceae). Al-Hadara Publishing, Cairo, Egypt. 2005.

20. Ghaedi, M.; Niknam, K.; Shokrollahi, A.; Niknam, E.; Rajabi, H.R.; Soylak, M. Flame atomic absorption spectrometric determination of trace amounts of heavy metal ions after solid phase extraction using modified sodium dodecyl sulfate coated on alumina. Journal of Hazardous Materials 2008, 155, 121-127, https://doi.org/10.1016/j.jhazmat.2007.11.038.

21. Yang, G.; Fen, W.; Lei, C.; Xiao, W.; Sun, H. Study on solid phase extraction and graphite furnace atomic absorption spectrometry for the determination of nickel, silver, cobalt, copper, cadmium and lead with MCI GEL CHP 20Y as sorbent. Journal of Hazardous Materials 2009, 162, 44-49, https://doi.org/10.1016/j.jhazmat.2008.05.007.

22. Mirzaei, M.; Behzadi, M.; Abadi, N.M.; Beizaei, A. Simultaneous separation/preconcentration of ultra trace heavy metals in industrial wastewaters by dispersive liquid-liquid microextraction based on solidification of floating organic drop prior to determination by graphite furnace atomic absorption spectrometry. Journal of Hazardous Materials 2011, 186, 1739-1743, https://doi.org/10.1016/j.jhazmat.2010.12.080.

23. Allen, S.; Grimshaw, H.M.; Parkinson, J.A.; Quarmby, C. Chemical Analysis of Ecological Material. Oxford, Blackwell Scientific Publication, 1974; pp. 521.

24. Tanhan, P.; Kruatrachue, M.; Pokethitiyook, P.; Chaiyarat, R. Uptake and accumulation of cadmium, lead and zinc by Siam weed [Chromolaena odorata (L.) King \& Robinson]. Chemosphere 2007, 68, 323-329, https://doi.org/10.1016/j.chemosphere.2006.12.064.

25. Song, B.; Xu, P.; Chen, M.; Tang, W.; Zeng, G.; Gong, J.; Zhang, P.; Ye, S. Using nanomaterials to facilitate the phytoremediation of contaminated soil. Critical Reviews in Environmental Science and Technology 2019, 49, 791-824, https://doi.org/10.1080/10643389.2018.1558891. 
26. Neidoni, D.G.; Nicorescu, V.; Andres, L.; Ihos, M.; Lehr, C.B. The Capacity of Lemna minor L. to accumulate heavy metals (zinc, copper, nickel). Revista De Chimie 2018, 69, 4153-4156, https://doi.org/10.37358/RC.18.11.6724.

27. Kinraide, T.B.; Poschenrieder, C.; Kopittke, P.M. The standard electrode potential (E $\theta$ ) predicts the prooxidant activity and the acute toxicity of metal ions. J Inorg Biochem 2011, 105, 1438-1445, https://doi.org/10.1016/j.jinorgbio.2011.08.024.

28. Cabot, C.; Martos, S.; Llugany, M.; Gallego, B.; Tolrà, R.; Poschenrieder, C. A role for zinc in plant defense against pathogens and herbivores. Frontiers in Plant Science 2019, 10, https://doi.org/10.3389/fpls.2019.01171.

29. Sela, M.; Garty, J.; Tel-Or, E. The accumulation and the effect of heavy metals on the water fern Azolla filiculoides. New Phytologist 1989, 112, 7-12, https://doi.org/10.1111/j.1469-8137.1989.tb00302.x.

30. Arora, A.N.; Sood, A.N.; Singh, P.K. Hyperaccumulation of cadmium and nickel by Azolla species. Indian Journal of Plant Physiology 2004, 3, 302-304.

31. Jafari, N.; Senobari, Z.; Pathak, R.K. Biotechnological potential of Azolla filiculoides, Azolla microphylla and Azolla pinnata for biosorption of $\mathrm{Pb}(\mathrm{II}), \mathrm{Mn}$ (II), $\mathrm{Cu}$ (II) and $\mathrm{Zn}(\mathrm{II})$. Ecology, Environment and Conservation 2010, 16, 443-449.

32. Khosravi, M.; Rakhshaee, R.; Ganji, M.T. Pre-treatment processes of Azolla filiculoides to remove Pb(II), $\mathrm{Cd}(\mathrm{II}), \mathrm{Ni}(\mathrm{II})$ and $\mathrm{Zn}$ (II) from aqueous solution in the batch and fixed-bed reactors. J Hazard Mater 2005, 127, 228-237, https://doi.org/10.1016/j.jhazmat.2005.07.023.

33. Miretzky, P.; Saralegui, A.; Fernández Cirelli, A. Simultaneous heavy metal removal mechanism by dead macrophytes. Chemosphere 2006, 62, 247-254, https://doi.org/10.1016/j.chemosphere.2005.05.010.

34. Rodrigues, A.C.D.; do Amaral Sobrinho, N.M.B.; dos Santos, F.S.; dos Santos, A.M.; Pereira, A.C.C.; Lima, E.S.A. Biosorption of Toxic Metals by Water Lettuce (Pistia stratiotes) Biomass. Water, Air, \& Soil Pollution 2017, 228, https://doi.org/10.1007/s11270-017-3340-6.

35. Ndeda, L.; S, M. Bio Concentration Factor and Translocation Ability of Heavy Metals within Different Habitats of Hydrophytes in Nairobi Dam, Kenya. IOSR Journal of Environmental Science, Toxicology and Food Technology 2014, 8, 42-45, https://doi.org/10.9790/2402-08544245.

36. Bokhari, S.H.; Ahmad, I.; Mahmood-Ul-Hassan, M.; Mohammad, A. Phytoremediation potential of Lemna minor L. for heavy metals. International Journal of Phytoremediation 2016, 18, 25-32, https://doi.org/10.1080/15226514.2015.1058331.

37. Branković, S.; Pavlović-Muratspahić, D.; Topuzović, M.; Glišić, R.; Milivojević, J.; Đekić, V. Metals Concentration and Accumulation in Several Aquatic Macrophytes. Biotechnology \& Biotechnological Equipment 2012, 26, 2731-2736, https://doi.org/10.5504/BBEQ.2011.0086. 